\title{
Human capital development and a Social License to Operate: Examples from Arctic energy in the Faroe Islands, Iceland and Greenland
}

\author{
Smits, Justinussen, Bertelsen \\ Energy Research \& Social Science 2016
}

Keywords: Social License to Operate, Human Capital Development, Arctic Energy

Word count: 10.747

\begin{abstract}
The Arctic region is opening up due to climate change, causing sea ice extend and snow cover to decrease. Over the past decade economic activities, including fisheries, shipping, oil \& gas, mining and tourism have increased throughout the region. Especially the oil and gas activities are subject to public debate and attract a lot of (international) attention. Obtaining and maintaining the support of local stakeholders is thus of major importance if governments and companies want to see these activities continue and contribute meaningfully to the resilience of Arctic societies. The concept of a Social License to Operate addresses the acceptance of an activity by local communities and other stakeholders. This manuscript explores the role human capital development in obtaining and maintaining a Social License to Operate in Iceland, the Faroe Islands and Greenland. As trust and legitimacy are the two fundamental principles on which a Social License to Operate is based, these are being examined more closely. On the basis of three case studies, this manuscript explores how human capital development can contribute to the legitimacy of Arctic energy development and trust building between various stakeholders.
\end{abstract}

\section{Introduction}

The Arctic region is opening up due to climate change, causing sea ice extend and snow cover to decrease (ACIA 2004). The effects of climate change are most profoundly felt in this part of the World, also called "the canary in the coal mine" (NASA 2013; The Economist 2004). Over the past decade economic activities, including fisheries, shipping, oil \& gas, mining and tourism have increased throughout the region. It is estimated that the resources to be found in this region could amount up to 90 billion Barrels of Oil Equivalent (BOE) and 1.670 trillion cubic feet of natural gas, which are technically recoverable (USGS 2008). This equals approximately $22 \%$ of the World's undiscovered technically recoverable oil and gas resources. With oil and gas, mining and shipping as the largest drivers, the Arctic could potentially attract over $\$ 100$ billion of investments (Lloyds 2012). However, these economic estimates were made before the drop in oil- and other resource prices, making these them currently questionable on the near- to mid-term.

The increase of Arctic oil and gas activities between 2008 and 2014 attracted a lot of attention and sparked public and political discussions on national, regional and international levels. The balance between economic development and environmental preservation is the main subject of these discussions. Already under pressure due to climate change, the oil and gas activities and the associated risks of an oil spill and pollution are seen as another threat to the sensitive Arctic ecosystem. At the same time, the (local) public debate is also focussed on the balance between local benefits and the risks associated with these activities. Since the region's own market for oil and gas is too small, the resources extracted in this region will be mainly transported to other parts of the World. How will the Arctic societies then benefit from these activities? And do these benefits compensate for the risks? As most of the resources are expected to be found in the Exclusive Economic Zone (EEZ) of the Arctic countries, the decision to and the way in which these activities are developed lies primarily in their jurisdiction. Also, there are already a number of mechanisms to ensure the maximisation of local benefits that are incorporated in their regulatory frameworks. However, the mechanisms currently incorporated into the legislation do not necessarily meet the expectations of societies and other stakeholders. As a consequence public debate or opposition can arise against a company's planned activities, even though it fully complies with all the rules and regulations set in a specific country. 
From a company's perspective, (negative) public debate and opposition is an undesired situation which can damage its reputation and become a costly affair. However, public debate and opposition is part of a democratic society and should therefore be respected. The trend is that the time for oil and gas projects to come online is increasing and has almost doubled in the past decade, making projects significantly more costly (Franks et al. 2014). Remoteness and scale play a role in this increasing trend, but part of it can also be explained by the increase of non-technical risks including public unrest. A concept that is increasingly used to address these non-technical risks is a Social License to Operate (SLO), which is aiming at obtaining and maintaining the acceptance and/or approval of an activity by local and other stakeholders. Paying attention to these social aspects of an activity is extremely important, especially in the Arctic region where deadlines are tight and the window of opportunity in the ice-free summer is limited. Missing any deadline here, would imply major delays and additional costs. Having not only the support of a national government, but also of the society at large is therefore crucial for companies having the ambition to operate in the Arctic. Moreover, given the long term timeframe these resources generally take to be developed it is important to build a sustainable relationship based on trust and mutual understanding. Public acceptance cannot simply be bought, tricked or fooled.

This article will explore the concept of a Social License to Operate in the case of offshore oil and gas development in the Faroe Islands, Iceland and Greenland. Although the cases have considerable differences, there are also a number of similarities that make them interesting for comparison in this article: All three are located in the North-Atlantic part of the Arctic, were or are still part of the Kingdom of Denmark and have small societies ranging between 50.000 and 350.000 inhabitants. We chose three case studies because a comparison could generate lessons learned and conclusions applicable to a wider scale, compared to focussing on one case study only. To ensure the quality of the gathered data one has to use data triangulation. By choosing three different methods of data collection it is ensured that findings or data are confirmed or disconfirmed in multiple ways (Yin 2009; Vennix 2006). This research is based on document analysis, participative observation and interviews. A total of 8 interviews were conducted with representatives of the industry $(n=3)$ and governments $(n=5)$. The authors of this article have a background in science and the private sector.

The first section will elaborate on the concept of a Social License to Operate. Thereafter the case studies of a Social License to Operate for oil and gas development in Iceland, the Faroe Islands and Greenland will be presented. In these case studies we will look at how the development of human capital stimulates the institutional and business sector strength of that specific country. Both the short and long term opportunities related to human capital development in relation to a Social License to Operate will be discussed. Finally, the findings of these three case studies will be discussed together, after which the article will end with some concluding remarks.

\section{A Social License to Operate}

\subsection{The emergence of the concept of a Social License to Operate}

The concept of a Social License to Operate emerged in the late 1990s, when it was first used by the Canadian mining executive Jim Cooney in a meeting with World Bank officials (Boutilier 2014). Since then, the term is increasingly used by business people, academia, consultants and media, and is still on the rise. Most research has focused on the application of this concept in the extractive industries, but is also used to an increasing extend in other sectors such as forestry, agriculture, renewable energy generation and pulp \& paper manufacturing (Hall et al. 2015; Moffat \& Zhang 2014). Until now the Social License to Operate concept has been predominantly considered from an industry point of view, while its application also makes it an interesting concept to look at from a government and civil society perspective (Hall et al. 2015; Morrison 2014).

Cross-sector research has indicated that the concept is differently understood among various (energy) sectors, and that its application changes in every context (Hall et al. 2015). Elements that are commonly present in many of the definitions are (ongoing) acceptance, approval, local communities, stakeholders and industry's activities (Hall et al. 2015; Moffat \& Zhang 2014; Thomson \& Boutilier 2011; World Bank 2003). Generally, in the literature a Social License is seen as an ongoing process that runs through the entire lifecycle of a project. It can be granted at one point in time but can be withdrawn again as well at another point in time. Often the withdrawal of a Social License to Operate 
for an activity happens much quicker than granting one. A withdrawal or lack of a Social License to Operate might not only affect the activity itself, but also has the potential to influence the reputation of a company and even an entire industry. The dynamic nature of a Social License to Operate requires companies to adapt and respond to changes if they want to secure and maintain the public acceptance of their activities (Prno 2013). Based on the aforementioned aspects, this article refers to a Social License to Operate as "the ongoing acceptance and approval of the activities of an industry by local communities and other stakeholders". This definition reflects the dynamic nature of a SLO and the fact that there are more than only local communities as stakeholders playing a role in this process.

One of the most challenging aspects of a Social License to Operate is the difficulty of measuring whether or not it has been granted. This also raises the question of who is granting the Social License to Operate. There will always be stakeholders opposing an activity, if only for fundamental beliefs or Not-In-My-BackYard (NIMBY) phenomena. The lack of a Social License to Operate is mostly measured based on the presence of protest and opposing voices in the public domain (Owen \& Kemp 2013; Prno \& Slocombe 2012). If there is protest against an activity, it is challenging to determine if this opposition represents the majority of stakeholders and the common interest, or not. One could argue that the loudest voice automatically 'wins', which goes against the democratic principles on which many societies are based. When an activity is in the interest of all other stakeholders, it does not necessarily mean that the one stakeholder opposing it holds a veto (Morrison 2014). Moreover activities may continue anyway when they are of regional or national importance (Yates \& Horvath 2013). On the other hand, measuring the existence of a Social License to Operate is difficult for a number of reasons too, as it is based on the assumption that a lack of objection means a Social License to Operate is present (Yates \& Horvath 2013). The lack of opposition or conflict in the public domain does not necessarily mean that stakeholders support or even accept the activity. The absence of publicly known objections and conflict may for example be caused by stakeholders disengaging from the project, cultural habits and customs or resistance voiced in less tangible/overt forms (Owen \& Kemp 2013). Thomson and Boutilier (2011) distinguish four levels of Social License to Operate: The lowest being the Social License withheld or withdrawn, then the mere acceptance of an activity, the level of approval when credibility is established and the level of psychological identification when trust is established.

\subsection{How to obtain and maintain a Social License to Operate?}

The previous section illustrated that having a Social License to Operate is essential for companies wanting to successfully implement their activities against budget and time, but how does one obtain a Social License to Operate? And is there only one Social License to Operate? Thomson and Boutilier (2011) have developed a framework in which the Social License to Operate is seen to exist on a continuum: The lowest end on the continuum is if a SLO is withdrawn or withheld. Other stages at this continuum range from acceptance and approval to psychological identification with an activity. A company cannot influence a SLO directly, nor can it unilaterally declare to possess one (Morrison 2014). A Social License to Operate is heavily reliant on trust and legitimacy, two aspects that are hard to measure and influence directly. The immeasurability and thus the inability to directly manage the concept itself, makes it difficult for companies to use this concept in existing management systems. However, via the concepts of economic legitimacy, interactional trust, institutionalised trust and sociopolitical legitimacy companies and other organisations can work on obtaining and maintaining their Social License to Operate (Thomson \& Boutilier 2011).

One of the most fundamental parameters are the local benefits (IIED 2014; Prno 2013). An imbalance between local risks and benefits could impede local support. The level of local benefits influences the economic legitimacy of an activity, which can be said to be one of the four fundamental factors of a Social License to Operate (Thomson \& Boutilier 2011). The payment of royalties and taxes to a national government does no longer suffice in many cases. Therefore a project proponent needs to look at creating a local knowledge base and employment. However, hiring a certain percentage of local workforce and contracting local businesses are only sustainable when linked to the broader economy (Harvey \& Bice 2014). Only then it can create greater resilience among local communities.

A Social License to Operate is built on relationships in which meaningful participation and the quality, not quantity, of stakeholder contact play a key role (Moffat \& Zhang 2014; Prno 2013). By building up a relationship via high quality contact that is perceived as positive and pleasant, stakeholders are less likely to feel taken advantage of (Moffat \& Zhang 2014). "The perception that the company listens, responds, keeps promises, engages in mutual dialogue and exhibits reciprocity in its interactions" 
(Thompson \& Boutilier 2011) is the very definition of interactional trust. There are also different levels of trust: One can define trust in a person (i.e. personal trust), which strongly relates to the element of interactional trust as discussed in this paragraph. Moreover, one can distinguish trust in an institution (i.e. institutionalised trust) which will be discussed later in this section. Personal trust is based on reciprocity, and built on knowledge of the behaviour of one to another over time. Trust is a two-way process and involves multiple parties. It is not something that can be declared to have obtained by a single actor. Trust can therefore be defined as a shared set of expectations between the actors involved (Zucker 1986). Essential in building trust between a company or industry and actors at a local level is the capacity of communities to meaningfully participate in the interaction with a company. These relationship-building processes often take a lot of time to build and maintain (Prno 2013), potentially requiring too much capacity of small societies to be able to fully participate in it. Therefore investing in capacity building programs for local societies does not only create a local workforce, but also enhances the capacity of a society to meaningfully engage with a company or industry. Local cluster development that includes businesses, knowledge institutes and government agencies offers the greatest opportunity for oil companies to build trust with local communities and other local stakeholders (Harvey \& Bice 2014).

More difficult to reach is institutionalised trust, since this requires stakeholders to perceive that the relationships between their institutions and the company are based on mutual trust with respect for each other's interests (Thomson \& Boutilier 2011). Institutional trust resembles the trust of societies in systems and institutions (Giddens 1990; Zucker 1986; Luhmann 1979), which has led to our modern day society in which we trust the political and monetary systems. Important elements of institutional trust are openness, transparency, order and predictability (Giddens 1990). The interaction with representatives of a system can influence the people's perceptions on the reliability of a system (Giddens 1990). People are more likely to trust a representative or leader of an institution, than the institution itself (Morrison 2014). At the same time this makes an institution dependent on the reputation and behaviour of its representatives and leaders. If an institution wants to be judged more objectively, rather than on emotional and irrational aspects, it needs to invest in creating informed communities (ibid.). When present, institutionalised trust often results in openly support for a specific activity or company. A Social License to Operate is also based on socio-political legitimacy, which relates to fairness, meeting expectations and contributing to the well-being of a region or country (ibid.). Procedural fairness is also a strong predictor of trust, because if the procedures of a company are perceived to be fair, stakeholders will better accept or approve a project regardless of the outcome of the procedure (Moffat \& Zhang 2014).

Working on all of the four abovementioned aspects will enhance the levels of trust and legitimacy, which could result in sustainable relationships with (local) stakeholders and ultimately in ongoing approval for an activity. In the case studies that follow, the role of human capital development will be explored not merely from a company's perspective. Also governments want to explore for and potentially develop oil and gas resources. Therefore a wider perspective will be used to look at the institutional context, potential historical path dependencies and country-specific policy measures that are in place to stimulate human capital development related to offshore oil and gas development. The different development stages, in which the energy- and more specifically the oil and gas sector is currently in, make these three countries an interesting comparison.

\section{Iceland}

Around 1900 Iceland was an overseas autonomy of the Kingdom of Denmark and one of the poorest societies of Europe. There was a strong political desire to expand political autonomy from Denmark and gain full independence, which was perceived as unrealistic by Danish political forces due to low socio-economic development in Iceland at that time. There was also a strong desire in Iceland to develop and diversify the economy away from its focus on agriculture and small-scale fishing (Nordal \& Kristinsson 1996). So it appears that there are parallels in the political and economic dreams of Iceland a century ago and later the Faroe Islands and today Greenland. Over time Iceland did achieve full independence and is today a highly developed country with a high level of human development (number 13 globally) (United Nations Development Programme n.d.). The interplay between human capital and natural resources has played an important part in enabling this development, and is very relevant for the Faroe Islands and Greenland in their aspirations for political independence and economic diversification (Bertelsen, Justinussen \& Smits 2015; Smits, Justinussen \& Bertelsen 2015; Bertelsen \& Hansen 2015; Smits, Bertelsen \& Justinussen 2014). 
Iceland thus offers a valuable case for discussing questions of legitimacy, local benefits and natural resources in very small North Atlantic Arctic societies, undergoing processes of political devolution. Iceland is a positive case that shows that a very small North Atlantic society through democratic governance and strong human capital can make legitimate decisions on natural resource use, and derive local benefits and sustainable development illustrated by the cases of geothermal and hydro power developments. The $19^{\text {th }}$ century energy developments in Iceland have led to the development of large scale hydropower activities that could potentially influence the (local) environment and nearby societies. The successful implementation of hydropower and geothermal power generation has diversified the Icelandic economy and brought the society knowledge, welfare and eventually independence. By thoroughly analysing this case, a number of success factors relevant to other small scale societies, like the Faroe Islands and Greenland, can be distinguished. These success factors relate to local benefits, legitimacy and interaction between the various parties involved, making them interesting for contemporary discussion about the concept of a Social License to Operate. This section will end with a brief discussion of the recent oil and gas developments, the Social License to Operate discussion related to this and if the historical success factors could be of use in the $21^{\text {st }}$ Century.

\subsection{Icelandic hydropower development}

In the late 1800 s there were many power intensive industries, such as for example nitrogen-based fertilizer plants. Hydropower could supply these industries with plenty of energy at low costs, and thus generated a lot of international attention at the time. Some Icelanders, such as Frímann B. Árngrímsson (1855-1936), recognised the hydropower potential of Iceland and wanted to implement large scale hydropower activities backed by foreign investments. At the time it was the lawyer, politician and poet Einar Benediktsson (1864-1940) who raised international capital for these large scale projects in Iceland. However the timing of his efforts was unfortunate, as the early 1900s Icelandic political environment was one of an independence struggle from Denmark, which did not allow for foreign-owned utilisation of Icelandic hydropower resources. In 1907 his efforts were rejected by the Althingi in the Waterfall Law, which required Icelandic residence for owners of waterfall rights. Later, in 1973, then governor of the Icelandic Central Bank Dr Jóhannes Nordal would regret that Iceland had not used its hydropower potential in the early 1900s. This could have supplied Iceland with technological knowhow and infrastructure at an earlier stage (Nordal 1973).

Even though foreign-owned hydropower development did not generate the necessary social and political support at the start of the $19^{\text {th }}$ century, the hydropower potential was not left unused. Local Icelandic communities and individual farmers electrified towns, villages and farms on a smaller scale. Through ready-to-assemble kits and brochures from abroad, this foreign technology and knowledge was implemented by Icelanders at a local level. In the late 1950s the highly politicised economic system adverse to foreign investment, for example related to hydropower supporting aluminumsmelting projects, broke down and a Conservative-Social democratic Viðreisnarstjórn (Restoration Government) took office. This new government sought to diversify and internationalise the Icelandic economy, and large-scale hydropower development financed by foreign investors to support the aluminum-smelting industry was an important part of it. It secured World Bank funding for the development of the Búrfellsvirkjun hydropower station, which started operating in 1969 and would be repaid by selling power to the Straumsvík aluminum-smelter of Alusuisse of Switzerland. At the time the electricity-sales agreement with Alusuisse was highly controversial concerning pricing of electricity to the foreign buyer compared to prices to Icelandic households, which has remained a contentious and complex question.

Where the Búrfellsvirkjun hydropower station was designed by Harza Engineering from Chicago, USA, and built by Icelandic workers, the situation changed and foreign technology and knowledge was transferred to Icelandic engineering companies from the 19070s through to the 2000s. Today, Iceland is renowned for its hydropower knowledge and technology, and exports it to the rest of the World. The strong (historic) connections of Iceland with foreign knowledge centres, the international exchange of knowledge, combined with strong primary, secondary, increasingly tertiary, and vocational education made the development of a locally controlled yet globally connected knowledge-based sector to a success. An important reason why this sector could be developed into a success and got a Social License to Operate of Icelandic society, even though it potentially has major environmental effects, was because of the high level of Icelandic involvement in the design, construction and operation of these plants and energy-consuming industries. The Icelandic political system has been able to adjudicate these trade-offs, which appear broadly legitimate within Icelandic society. However, this 
legitimacy has been questioned by foreign environmental NGOs during the development of the large hydropower station Kárahnjúkavirkjun, which was opened in 2009.

\subsection{Icelandic geothermal energy development}

The development of geothermal energy in Iceland materialised earlier compared to the development of hydropower. It was Valtýr Guormundsson (1860-1928), an Icelandic member of the Althingi at the time, who was interested in geothermal energy and wrote an influential article about geothermal heating in Idaho, USA (Guðmundsson 1910). From 1930 and onwards, Iceland developed an extensive geothermal infrastructure starting with the heating of the public primary school of Austurbæjarskólinn and the public swimming pool in Reykjavík. Today, all areas of Iceland where it is possible to obtain geothermal energy are heated by this hot water and steam technology. In regions where this is not possible, hydropower is used to generate electricity for heating. Geothermal energy was a signature Icelandic resource and technology, controlled and financed by Icelanders who heated their homes and swimming pools that were the pride of the nation to foreign visitors. The geothermal revolution in Iceland was more indigenous than the hydropower and therefore much less controversial.

However, geothermal energy recently became more controversial with the increased size of the installations. The large installations also come with a greater environmental impact, including the increase of noise and smell. Future large-scale geothermal installations will likely be used for electricity generation meant for the export, either by subsea power lines or power-intensive industries. It is thus no longer meant to heat the homes of Icelanders, making the benefits of geothermal energy generation less tangible for society while the local impacts increase. For this reason future geothermal energy could become as controversial as hydropower has long been. However, the likelihood of this controversy is mitigated by the strong Icelandic human capital involved in the development of geothermal energy. Icelandic companies, government and universities have built strong competences that are relevant on a global scale, especially now that the World is looking for options to generate renewable energy that substitutes fossil fuels and facilitates the energy transition to mitigate climate change (Pálmason 2005; Friðleifsson, Svanbjörnsson \& Thorsteinsson 1984).

\subsection{The historical success factors in creating societal acceptance and legitimacy}

Iceland has managed to build a worldwide renowned hydropower and geothermal energy sector, which is controlled locally and based on the strong presence of Icelandic human capital. Especially related to the hydropower development the involvement of foreign investors was controversial for a long time. Iceland did not want to be controlled any longer by foreign decision makers, which resulted in the rejection of foreign investments during the first half of the $20^{\text {th }}$ century. That is also the reason why the more Icelandic based geothermal energy development could take place on a larger scale at an earlier moment in time. Based on this case study one of the success factors for societal acceptance and legitimacy of implementing new energy activities is therefore the involvement of Icelanders in the design, construction and operation, thereby generating clear benefits at a local level.

However, to be able to participate and benefit from these new opportunities at a local level, people should have the right knowledge and skill set. Concerning geothermal energy a strong human capital base was already present in Iceland from the start, however related to large-scale hydropower this had to come from abroad. Only when opening up to foreign investments, and thereby creating the opportunity to transfer knowledge and skills to Iceland, a successful hydropower sector could be developed. Here Iceland benefitted from the existing quality of its local primary, secondary and vocational education, as well as its long tradition in undergraduate and more recently postgraduate education that is provided in Icelandic by Icelandic institutions. (Bertelsen, Justinussen \& Smits 2015; Smits, Justinussen \& Bertelsen 2015; Smits, Bertelsen \& Justinussen 2014; Bertelsen, Hansen 2015). Local education and human capital development combined with a long tradition of Icelanders going abroad to study or work at leading European and North-American knowledge institutes and companies, proved to be one of the key success factors in securing local benefits and thereby the acceptance of the development of new energy sectors.

Within the development of a successful hydropower and geothermal energy sector an important role was reserved for the Icelandic government. Not only was the government responsible for blocking any foreign investments and therefore knowledge transfer in the first place, it also played an important role in securing that Iceland would sufficiently benefit from these new developments. At a very early stage, even before the hydropower and geothermal energy activities came to the fore, it invested in educational institutes so that a human capital base was created. Later, it took the lead in securing 
World Bank funding and made sales-agreements with private sector companies. Furthermore it adjudicated controversies and environmental trade-offs. Taking the lead in these matters and acting as an interface between the private sector and Icelandic society, proved to be successful in addressing existing controversies and potential environmental impacts.

\subsection{The recent development of a new energy sector: Offshore oil and gas}

Currently, Iceland is venturing into a new energy sector, namely offshore oil and gas in the Northeast corner of Iceland's Exclusive Economic Zone also known as the Dreki area. The reason for the recent interest is the settlement of border disputes around Jan Mayen Island with Norway, concluding that each state has a $25 \%$ share in licenses on the other side of the border. At the moment two licenses to search of oil and gas in this area have been granted. One is owned by a consortium of the Chinese national oil company (CNOOC International), which has a $60 \%$ share and is also the operator, the Icelandic Eykon Energy ehf (15\%) and Petoro Iceland AS (25\%). The second license is owned by a consortium consisting of Ithaca Petroleum ehf.(operator) with a 56,25\% share, the Icelandic Kolvetni ehf. (18,75\%), and Petoro Iceland AS (25\%) (National Energy Authority Orkustofnun n.d.).

Iceland has little experience and local knowledge about offshore oil and gas exploration and production. However, interviews with Icelandic authorities and companies reveal strong selfconfidence based on a generally high-level of international science and engineering skills, knowledge and experience. Knowledge-transfer from Norway facilitated by Scandinavian educational and professional experience of Icelanders plays a significant role here. Icelandic authorities have prepared and Althingi passed new legislation to regulate the licensing of oil and gas activities (personal communication with four Icelandic Government Representatives). And Icelandic companies seem confident that they will be able to secure their share of this development by servicing the international oil companies (personal communication with two Icelandic companies). There is no aversion to foreign investment related to this development, and both authorities and companies are confident they can secure ample of local benefits from this development.

The Icelandic public debate on offshore oil and gas production appears to focus on Iceland's global climate responsibilities and green image, rather than being exploited by large international oil companies and foreign investment. The importance of economic legitimacy or local benefits from the offshore oil and gas activities seems not to be at the core of societal debate these days. Also, there seems to be a general level of trust in the international oil and gas companies that would execute these activities. The focus of Icelandic societal debate today, is on the socio-political legitimacy of these activities. Especially in the light of the recent Paris Global Climate Change Agreement, the legitimacy of starting new activities leading to fossil fuel extraction can be questioned. Also, it would concern resources that would be exported as Iceland does not need the additional resources to generate electricity or heat. At the same time gas is seen as a transition energy source on the path towards a renewable society, and could help other countries to speed up this transition moving away from the use of coal and oil.

According to Thomson \& Boutilier (2011), if the socio-political legitimacy of an activity is lacking while maybe the economic legitimacy and interactional trust are still present, the Social License to Operate of an activity may at best be approved but could also be withdrawn. The largest amount of stakeholders is likely to grant an acceptance level of the Social License to Operate for these activities. At the same time the socio-political legitimacy, such as the role of certain activities or industry in the face of climate change is not something that individual companies can easily influence. It is therefore becoming much more of a global challenge, also involving a broader set of stakeholders. The sociopolitical legitimacy aspect of a Social License to Operate therefore closely relates to a company's or even industry's level of involvement in the challenge of developing a global social contract for global problems such as climate change (Thomson \& Boutilier 2011).

\section{The Faroe Islands}

In the Faroe Islands the development of an energy sector in the form of oil and gas started during the 1990s, after Denmark transferred the rights to underground resources to the Faroe Islands in 1992. Before that, the Faroe Islands were a dependent territory of the Kingdom of Denmark since the Treaty of Kiel in 1814. There was no incentive for the Faroese authorities to proceed with oil and gas exploration, as long as the rights to the underground were in the hands of Denmark. Under the Home Rule System, which came into force in 1948, all policy domains were placed on either 'List A' or 'List 
B'. The policy domains on List A could be taken over by the Faroese government at any time, while the domains on List B could only be taken over after negotiation and agreement with the Danish government. Since 1948 several attempts were made to gain authority over the rights to underground resources, which were on List B (Harhoff 1993). In 1992 the Danish government unexpectedly changed its mind. Without having to go through Parliament (Folketinget), the Danish government and Prime Minster at the time Poul Schluter, decided to transfer these rights to the Faroe Islands. On the $22^{\text {nd }}$ December 1992 the agreement between Denmark and the Faroe Islands was signed. The Faroe Islands had secured the rights to all mineral and hydrocarbon deposits in the Faroese underground (Harhoff 1993; Müller and Djurhuus 2014). The transfer was transformative and kicked off a whole new phase of socio-economic development in the Faroe Islands (Bertelsen et al. 2015).

With the rights to the underground secured, the Faroese government decided to start preparing for a future oil industry. It established the Hydrocarbon Planning Commission to investigate how future Faroese oil exploration and production legislation could be designed, and in such a way that it would mostly benefit the Faroese society. More specifically, the goal of the Commission was to advise the government on a future oil extraction policy and how labour, industry and social interest could be ensured in the best way possible if oil exploration and extraction should become reality (Oljuráoleggingarnevndin 1997: 13). In terms of the Social License to Operate concept, the private sector was thus stimulated by policy measures in the regulatory framework to think and act on maximising the local benefits and working on the economic legitimacy of their activities. In this case study it is examined whether the measures set out in the regulatory framework were sufficient for the companies to ensure their economic legitimacy for the Faroese society. Furthermore, this section will examine whether there have been other success factors related to the Social License to Operate for the development of an oil and gas industry in the Faroe Islands.

\subsection{Stimulating socio-economic development from the start}

Based on the advice from the Hydrocarbon Planning Commission, the key component of the regulatory framework was based on three main principles (Oljuráoleggingarnevndin 1997):

1. All personnel and material to and from the oil platforms must pass through a Faroese harbour;

2. The Faroese workforce and industry should be given a fair and real chance to participate in the activities related to oil exploration and extraction; and

3. License holders had to financially commit to a Faroese Competence Development Fund that was to be used to finance education, research and other exploratory activities.

These three principles, stimulating foreign companies to engage and support the Faroese society, are now regarded as one of the success factors in the development of an oil and gas sector in the Faroe Islands. At that time, in the 1990s, the industry of the Faroe Islands had no experience in the oil and gas sector and very few, if any, personnel working for oil companies. If one were to take a snapshot picture of the Faroese society anno 1998, there would not be any businesses that would have a chance to participate in the oil industry, and even fewer educated oil industry people. As a fishery nation however, many of the maritime skills could potentially be transferred to the offshore oil and gas industry. It was however clear from the beginning that if society was to benefit from the hydrocarbon activities, a deliberate effort should be made to develop the necessary skill sets and experiences, and a massive investment had to take place in entirely new sectors.

The three principles of the hydrocarbon legislation in the Faroe Islands were introduced to stimulate a broad socio-economic development. However, also from the side of the oil companies themselves there was an interest in promoting such development and fund research in the Faroe Islands. According to Anderson et al., who studied BP and its engagement prior to entering the Faroe Islands "Cultural research was also regarded as 'very necessary before entering the Faroe Islands ... in order to] get a good reputation before [it] even started drilling'. BP reported having substantial contact with Faroese representatives before maintaining a physical presence there. Furthermore, such 'pre-work' was deemed 'invaluable'." (Anderson \& Bieniaszewska 2005). This 'pre-work' is well documented in a recent publication by two Faroese journalists, Jan Muller and Tróndur Djurhuus, who closely followed the development of the oil industry in the Faroe Islands (Müller and Djurhuus 2014).

In 1999 both journalists were part of a team of sixteen key 'influencers', including industry representatives, politicians, civil servants, academics, and journalists, from the Faroe Islands. The key influencers were invited on a trip to Alaska, which was paid for by BP, to study and see the oil fields 
and learn how the oil industry interacted with local communities over there. The two journalists were surprised by the opulence they were suddenly offered and commented: "Faroese news reporters and others don't have to live in double rooms, or student residencies, when they go abroad in 'offshore errands'. Now there is space for them in four and five star hotels. The scoop and the 'sitting bathtub' is replaced by a huge bathroom of marble, and we dined well, without anybody having to think about to whom the bill will be sent to" (Müller and Djurhuus 2014: 97). In Alaska, the team was met with one key message repeatedly: Oil exploration and oil extraction can be organized in a way that benefits both the oil industry and society as a whole. According Djurhus, "Texaco does not hide that they hope that it [the trip to Alaska] also will benefit the oil companies, once the Faroese know how other societies cooperate with the companies. Over and over the slogan on the trip is win-win" (Müller and Djurhuus 2014: 123). Since the late 1990s, many influencers from the Faroe Islands have been invited to join similar trips, as this was a strategy pursued by the major oil companies at that time.

\subsection{Local benefits after 15 years of exploration}

In 2001 the first oil exploration well was drilled and the exploration for hydrocarbon resources in Faroese waters had officially begun. After 15 years of exploration, a lot of experience and knowledge has been gained in the Faroe Islands, but no oil has been found (yet) in commercially viable amounts. Nevertheless, the exploration activities are ongoing and have led to some major spin-off activities with significant socio-economic effects on a national level. An entirely new hydrocarbon cluster was created, consisting of new companies and offering new support to existing companies (Bertelsen et al. 2015; Müller and Djurhuus 2014; Smits et al. 2014). Parties that are participating in this hydrocarbon cluster include for example:

- Oil Companies (Atlantic Petroleum, Faroe Petroleum)

- Offshore supply companies (Skanksi, Thor, Jacobsen)

- Shipyard (MEST)

- Offshore Supply Services (Faroese Offshore Supply Services)

- IT (Simprentis, Føroya Tele)

- Harbor (Atlantic Supply Base)

- Petroleum Administration (Jarðfeingið)

- University of the Faroe Islands (Fróðskaparsetur Føroya)

- Maritime College (Vinnuháskúlin)

- NewsPortal (www.oljan.fo)

Important drivers in the creation of this cluster were the three principles on which the institutional setup was based. For example, the legal requirement that all material destined for the oil platforms in the Faroe Islands must go through a Faroese harbour, has led to the creation of a new Atlantic supply base in the Faroese city of Runavik (Atlantic Supply Base 2011). The requirement that oil companies must give Faroese businesses and labour a real and fair chance to participate in activities of the industry, has led to the establishment of new offshore companies and the employment of Faroese personnel on platforms (Krúnborg Offshore 2012; Mest 2013; Skansi 2013; Thor 2011). The requirement to financially support the competence development fund has resulted in the investment of 180 million DDK on over 500 competence development projects (Eliasen 2013). Also, as a result of spin-offs from these pillars, a growing number of citizens from the Faroe Islands have found work in the oil sector abroad. Migration between the Faroe Islands and the platforms abroad is bringing in about 824 million DDK a year to the Faroese economy (Hagstova Føroya 2012). All in all, 942 people, representing $3.4 \%$ of the total active labour force, were working within the hydrocarbon sector in 2013 (Hagstova Føroya 2015; Oljuvinnufelagið 2013).

This leads to an interesting observation: Until now, there is no commercially viable oil in the Faroe Islands, yet the nation has developed a substantial hydrocarbon cluster that competes at a global level. This implies that the competitiveness is not based on the presence of oil deposits in the Faroe Islands, because there are none found, but rather on the human capital that has evolved as a result of the particular development path that has been intentionally and strategically pursued since the late 1990s. As a whole, this has benefited Faroese society and has also given the hydrocarbon industry a high degree of economic and socio-economic legitimacy in terms of a Social License to Operate.

\subsection{Trust building between stakeholders in the hydrocarbon cluster}

The cluster development described above has also added a new dynamic to the Faroese society, as these players interact at local and international conferences, offshore business fairs, and in joint 
ventures. This dynamic creates an ongoing dialogue - and competition of course - between these actors. Furthermore, the competence development fund has been managed in a way that can be described as a co-management system, in which the oil industry (licence holders) and the government administer the funds jointly. On the one hand, the companies were obliged to commit a certain amount of funds to the competence development fund. All applications to the fund had to go through the Petroleum Administration (Jarðfeingi), where jointly the formal eligibility is established and all applicants and grants are registered. However, the oil companies had, and still have, the final say on which project to fund. Thus the final decision on whether a PhD research project is granted or not, is taken by the oil company and the student receives a personal letter from the oil company, not from the Petroleum Administration (Jarðfeingi 2016; Oljumálaráðið 2003). This new cluster development and the co-management of the competence development fund, has led to an increasing and ongoing interaction between the Faroese oil administration, the oil industry, the Faroese business community and Faroese civil society. Over the past 15 years relations between these stakeholders have been built in multiple ways and in multiple platforms for cooperation. This has created a basis of interactional trust between the various stakeholders involved.

All in all, the clear local benefits and increased cooperation between stakeholders over the past two decades has resulted in a high score on the Social License to Operate continuum for the oil and gas activities in the Faroe Islands. How high the Social License to Operate is exactly, is difficult to pinpoint. However, it is a fact that there has not been a single protest or demonstration against the oil companies and their activities until now. Nor are there any social movements such as NGOs, political parties, or any other groups that are against oil exploration in the Faroe Islands. Instead, there is a high degree of positive expectation and support for the industry in the Faroese society.

It is evident that the oil companies that were involved in the early development of the oil sector in the Faroe Islands, even before the actual exploration began, were concerned about the perceived legitimacy of their business in the local society, and there seems to have been a convergence of the political wishes for inclusive growth and the strategy pursued by the major oil companies. This is regarded as a success factor contributing to the effectiveness of the regulatory framework and ensures the hydrocarbon sector's Social License to Operate in the Faroe Islands.

\section{Greenland}

With a surface of more than 2 million square kilometres Greenland is the largest island of the World (www.cia.gov). Approximately $81 \%$ of the island is covered in ice, explaining why Greenland's society lives scattered along the 44.000 kilometres long coastline. At the same time, Greenland is considered to be a microstate based on the small size of its society which consists of approximately 56.000 people. Today, Greenland is still part of the Kingdom of Denmark but has Home Rule since 1979 and Self Rule since 2009 (Smits, van Tatenhove \& van Leeuwen 2014b). The Self Rule implies that only defence, foreign policy and security are shared responsibilities between Denmark and Greenland (Smits et al. 2014b). The underground and its resources belong to Greenland. Eventually it is the ambition of Greenland to become (financially) independent from Denmark, although the timeframe in which this goal should be realised is subject to debate. In order to become financially independent, the national economy that is now mainly dependent on fisheries, tourism and the public sector, needs to be diversified. The development of oil and gas but also mining activities is seen as an important element in this strategy (Naalakkersuisut 2014a). Based on the estimations of the U.S. Geological Survey (2008) it is expected that the Greenlandic waters contain large oil and/or as reserves. Over the last 40 years a limited number of exploration activities have been undertaken in Greenland's Extended Economic Zone: In the 1970s a total number of 5 exploration wells were drilled followed by 1 in 2000 and another 8 in 2010/2011. Moreover, multiple sets of seismic data as preparation for (future) exploration drilling activities have been acquired over time.

The strategy of the Greenlandic government to develop oil and gas resources and the recent exploration drilling activities in 2010/2011 by Cairn Energy have attracted a lot of public attention, both on the national as well as the international level. On both levels there are stakeholders with different opinions on this matter, and stakeholder groups are divided on this topic. The risk of an oil spill and other potentially negative impacts on the fragile ecosystem is the main topic of the discussion, along with the importance of this ecosystem and its marine mammals for local societies (Pfeifer \& Thompson 2011). Because the past activities have sparked debates in society, one cannot assume to have a Social License to Operate at the start of (future) activities. Therefore the government as well as the companies that would like to start their activities in the Greenlandic waters need to take into account 
the potential non-technical risks. As legitimacy and trust are regarded as two of the main underlying principles in obtaining and maintaining a Social License to Operate (Thomson \& Boutilier 2011), focussing on these elements in a project's development strategy could contribute to obtaining and later sustainably maintaining a Social License to Operate. This section explores how human capital development could contribute to trust building and legitimacy of oil and gas activities in Greenland. It will primarily focus on the role of human capital in relation to the economic legitimacy of an activity, as this is the basis of a Social License to Operate. Moreover the role of human capital related to interactional trust will also be examined. Findings from the case studies of Iceland and the Faroe Islands will be used to determine a number of potential success factors in the Greenlandic context.

\subsection{Human capital development and the economic legitimacy of oil and gas activities in Greenland}

As is the case in the rest of the Arctic region, Greenland's economy is considered a small market (Ackrén, Nielsen \& Harms 2011) meaning that the majority of the resources would be shipped to global markets elsewhere. The most important challenge for Greenland's society and government is to maximise the local benefits from the (future) oil and gas activities (Naalakkersuitut 2014b; Smits et al. 2014ab). Local benefits are also an important basis for a Social License to Operate, as is illustrated by the 'economic legitimacy' principle of Thomson and Boutilier (2011). The regulatory framework in Greenland already includes a number of policy measures to stimulate the involvement of local stakeholders in the development of an activity. Working on these requirements to the best extend possible can contribute to a Social License to Operate. However, assuming that only compliance with these requirements will be sufficient is naïve and should be examined on a continuous basis throughout the development process of an activity.

In order to maximise the (economic) benefits at a national level, the Oil \& Mineral Strategy 2014-2018 aims to sustainably develop oil and gas activities by prioritising the industry's interfaces with education, the labour market, existing infrastructure and social services (Naalakkersuisut 2014b). However, in order for society to maximally benefit, it needs to have the right education and qualifications to be able to participate in the industry (Bertelsen, Justinussen \& Smits 2016). These requirements do not only apply to individuals, but also to local businesses. Even though it can be questioned whether there will be any exploration drilling in the coming few years and thus why any knowledge in this field should be developed, the development of human capital and getting the right qualifications takes time. Increasing the level of education has already been a focus point for the government of Greenland over the past decade. Greenland does not have an extensive history of developing a knowledge-based economy via higher education and knowledge exchange, such as Iceland and the Faroe Islands (Smits et al. 2014a). Under the "Greenland Education Program" (www.nanoq.gl) the number of post-primary graduates has increased. However, creating a critical mass of (highly educated) human capital remains a challenge.

To ensure that the industry contributes to this challenge, the government has incorporated the Impact Benefit Agreement (IBA) as a policy measure in the Mineral Resources Act, which is the central regulatory framework concerning the development of oil and gas resources. The aim of the Impact Benefit Agreement is to "enhance and secure the involvement of relevant Greenlandic stakeholders" (Naalakkersuisut 2014c), and by doing so, increasing the positive impacts of the industrial development on the Greenlandic society. Since all oil companies that want to perform activities in Greenland need to agree on an Impact Benefit Agreement with the Greenlandic government and the affected municipalities, this forms a good starting point to work on the important Social License to Operate elements of trust and legitimacy. However, the outcomes of an Impact Benefit Agreement itself are focussing on the short- and mid-term when negotiated in relation to exploration activities. Of course the government can ensure that the agreement successfully contributes to the country's long term goals, by having their strategy in mind during the negotiations. If companies want to build a sustainable, long term relationship with local stakeholders, one should not only focus on the Impact Benefit Agreement alone.

Besides the formal requirements of an Impact Benefit Agreement, there are a number of ways in which companies could contribute to an increased human capital base in Greenland. Various initiatives in this field already exist and could form a starting point for engaging with local stakeholders and businesses. Preparing Greenlandic businesses for participation in the oil and gas industry is one of them. In 2012 the government started to support local businesses in raising their profile and by granting support to diverse and self-sustaining initiatives in order to strengthen the development of the national economy. Another way to start engaging with local businesses is via existing partnerships (i.e. 
suppliers.gl) that aim at the oil and gas industry. These partnerships could serve as a link between the International Oil Companies and local businesses. Knowledge exchange and capacity building are already on their agenda and could be further enhanced by the involvement of international knowledge and expertise from the International Oil Companies.

By contributing to human capital building international companies do not only comply with the regulatory framework and international best practice, but it could also be a basis for creating economic legitimacy of their activities and thus their Social License to Operate. Increasing and tailoring the skills and qualifications of people in order for them to be able to participate and contribute to the industry and its related activities, will enhance the (economic) benefits at a local level. However, only working on the economic legitimacy will only create an uncertain basis for a Social License to Operate, which is dependent on three more factors according to Thomson and Boutilier (2011). The following section will explore the role human capital development could play in relation to creating interactional trust.

\subsection{Human capital development and trust building between stakeholders}

As is concluded based on the Faroe Islands case study, human capital development could also serve as a platform to build trust between various stakeholders. This relates in the first place to what Thomson and Boutilier (2011) call 'interactional trust' and could ultimately lead to more 'institutionalised trust'. The legal framework already requires companies to engage stakeholders during the permitting process, for example via consultation rounds (BMP 2009). The government facilitates this process and sometimes functions as an intermediate between large international companies and small Greenlandic societies (personal communication Greenland Government representative January 2016). By delivering what has is promised during the consultation process, a company has the opportunity to show their responsibility and build trust among local stakeholders. Even though the Greenland Government is in the process of revising the Social Impact Assessment procedures and requirements, these consultation processes are of a relatively short duration ( 6 weeks, with the possibility of extension) and limited to the permitting process prior to the activities itself.

Another opportunity to build trust between a private company and Greenlandic stakeholders is the Impact Benefit Agreement. The negotiation procedures involve not only the private company and the national government, but also the affected municipalities. Furthermore, the IBA is focussed on the use of Greenlandic labour and enterprises when performing activities in Greenland (BMP 2009). This forms a basis to discuss the requirements and qualifications the industry needs from skilled labour and businesses, in order for them to participate in the industry. However, the formal stakeholders involved in the negotiation process are limited, as they do not include Greenlandic knowledge institutes and workers' associations (Ministry of Industry, Labour and Trade 2015; BMP 2009). Moreover, the recent activities of the oil and gas sector were ad hoc and of a short duration (personal communication Greenland Business representative January 2016), making it difficult to establish a sustainable relationship build on trust.

Establishing a Greenlandic Industry Cluster, including the international company/companies, government authorities, local businesses, NGOs / associations and knowledge institutes, according to Faroese example, is an opportunity to create trust when exploration activities would take place again in the future. Existing initiatives from the Greenlandic government or Greenlandic NGOs such as CSR Greenland, could serve as a basis for cooperation in such a multi-stakeholder cluster on human capital development.

\section{Discussion}

Although the three case studies each have a different context and are at a different stage in the development of an energy sector, whether it is oil and gas, hydropower or geothermal energy, a critical comparison generates a number of valuable insights. The development of an energy sector and using this for export or to support energy-consuming export industries is or has been pursued by all three states to diversify their economy and boost socio-economic development. Having a Social License to Operate for these activities is of major importance in making this strategy a success. As appears from both the Icelandic and Faroese case study, it is crucial for an activity to have clear local benefits and thereby secure its economic legitimacy. More specifically, to generate this economic legitimacy and thereby create a Social License to Operate at acceptance level, these benefits should not only result from taxes and royalties but rather from participation of local communities in these new activities. Participation can be anything in the range from design, construction or operation. However especially in the case for large-scale developments, the local involvement should be substantial as was shown 
by the case of Iceland. Large-scale foreign investments were rejected at first, because of little involvement of Icelanders in phases other than construction, and the fear of being dominated again by foreign powers. Later, when more experience was gained with small-scale hydropower Iceland felt more in control and foreign investments were seen as the key to socio-economic development. Only then the large scale hydropower installations were developed. Gradually, knowledge was transferred to Icelandic businesses, allowing for the development of hydropower to become fully Icelandic. And even though there are potentially large (environmental) impacts from large-scale hydropower development, the Social License to Operate is still present. Over time, Iceland has developed itself as a global player in the field of hydropower and Icelandic experts and businesses are now exporting their knowledge to other places in the World.

Substantial involvement from the start and knowledge transfer during the development of a new industry seems to be a crucial element for the Social License to Operate. This is also underpinned by the case of the Faroe Islands, where involvement of the Faroese society and businesses was not only stimulated from the start by a number of policy measures, but was also explicitly present in the strategy of the international oil companies. Since the exploration activities started, much attention has been paid to knowledge transfer and development. Within 15 years this has led to Faroese businesses being established, which do not only participate in the industry at a national level but also export their knowledge and experience to other places in the World. Compared to Iceland, the Faroe Islands have implemented more requirements in their regulatory framework to ensure society would benefit sufficiently from these new activities. A reason could be because there was no experience whatsoever with oil and gas in the Faroe Islands prior to the start of the exploration activities in 2001. Iceland however already had some experience with hydropower, albeit as small-scale hydropower, when it attracted foreign investments. From the Greenlandic case it appears that Greenland is following the same strategy as the Faroe Islands, and has implemented a number of policy measures such as the Impact Benefit Agreement to ensure involvement of Greenlandic society in new developments.

When requiring or desiring substantial involvement of a local society in new industrial activities, the right set of skills and knowledge should be available among the local workforce and businesses. This is thus not only in the interest of national governments, but also for international private sector companies. As the cases of Iceland and the Faroe Islands show, the high level of involvement from local people and businesses in new industrial activities generates clearer benefits for society and has the tendency to create a firm basis for a Social License to Operate. However, at the start of such new developments there is not necessarily a lot of knowledge and expertise in this field available among the workforce. The challenge is then to create the knowledge and expertise needed for these new activities, while ensuring that society is already involved from the start. For this reason the authors argue that human capital development plays a vital role in securing the local benefits and economic legitimacy of an activity, thereby contributing to obtaining and maintaining a Social License to Operate. Ideally the development of relevant knowledge and expertise should start prior to start of (large-scale) development of new activities. This facilitates the high-level involvement of society, as is shown by the Icelandic case. However if this is not possible, society could look at existing knowledge and try to apply that in the new industry, or base human capital development programmes on the already existing skills and expertise. This is how the Faroe Islands have transformed their offshore knowledge from fisheries into useful skills and expertise for the oil and gas industry. Establishing a fund to stimulate human capital development, which is co-managed by the industry and the government, is enhancing this process.

Next to the economic legitimacy, the focus on human capital development can also contribute to the creation of interactional trust. The hydrocarbon cluster that was formed in the Faroe Islands brought together various stakeholders ranging from government authorities, private sector international and national businesses to knowledge institutes. Stimulated by the regulatory framework, these stakeholders started coming together in this cluster and established a more institutionalised dialogue and cooperation. While working together on competence development projects and interacting over the past years, these stakeholders have been able to show each other that they deliver as promised. Relationships are built, adding to a better mutual understanding. As a wide variety of stakeholders is included in this cluster it covers different parts of society, leading to a broader acceptance. These are elements that all contribute to a more established Social License to Operate.

A discussion that particularly relates to the development of fossil fuels is whether it contributes to the future of a society in terms of sustainable development, energy transition and climate change. In 
Iceland this is the main subject of societal debate related to the oil and gas exploration in the Dreki area. Also in Greenland there are critical voices in society that focus on this element. Regarding a Social License to Operate for oil and gas activities, this relates to the socio-political legitimacy of an activity. This is an element that is difficult to influence by one company or stakeholder alone, and is something that requires the input of multiple stakeholders on a larger scale. However, this does not mean that a company or stakeholder should not look at what can be done at a smaller scale or within its own circle of influence. Focussing on gas as a transition fuel towards renewable energy is for example regarded as a more responsible attitude compared to focussing on the production oil. The socio-political legitimacy aspect of a Social License to Operate therefore closely relates to a company's or even industry's level of involvement in the challenge of developing a global social contract for worldwide problems such as climate change.

\section{Conclusion}

In this article the role of human capital development related to obtaining and maintaining a Social License to Operate for energy activities, including oil and gas, hydropower and geothermal energy, has been examined based on case studies from Iceland, the Faroe Islands and Greenland. Where Iceland and the Faroe Islands have already established an energy sector that allows them to export knowledge and expertise elsewhere, Greenland finds itself at the start of such development. Based on the Icelandic and Faroese cases, human capital development plays an important role in maximising local benefits and thereby securing the economic legitimacy of the new industrial activities. The economic legitimacy is the first element of a Social License to Operate and can generate an acceptance level for an activity among society. Important in this respect is to ensure substantial involvement from local people at the start of the new activities, and focus on knowledge transfer and development throughout the development process of an activity.

When there is no previous experience with the specific industry that wants to develop these new activities, this involvement and knowledge transfer can be stimulated by incorporating policy measures into a state's regulatory framework. This has proved to be a success in the Faroe Islands, and also Greenland is preparing itself for the development of a new energy sector in similar ways. For the local workforce to be able to participate in the new activities, their knowledge and skills should be applicable to this new industry. Focussing on human capital development is therefore essential. This is not only in the interest of a government, to ensure the benefits for its society are being maximised, but also for private sector companies in terms of their economic legitimacy and thus Social License to Operate. As human capital development requires the input of multiple stakeholders, the creation of a cluster as happened in the Faroe Islands can facilitate this process. Moreover, this cluster offers a platform for interaction between the different stakeholders over a longer period of time, thereby stimulating interaction and trust building between the parties involved.

Human capital development thus contributes in multiple ways to obtaining and maintaining a Social License to Operate for new energy activities in these three North Atlantic Arctic states. The main contribution is made related to the economic legitimacy of an activity via the maximisation of benefits at a local level. Maximising local benefits from these foreign investments was and is essential for all three societies. Especially in the light of a pathway towards independence, the economic diversification and benefits that come from the energy sector development are of major importance. In this context, the success factors for Iceland and the Faroe Islands that are identified in this article could be of interest to Greenland. 


\section{References}

ACIA. (2004). Arctic Climate Impact Assessment. New York: Cambridge University Press.

Ackrén, M., Nielsen, S., \& Harms, M. (2011). Greenland's economy in perspective for future endavours (Final draft). Retrieved 16 November 2014, from http://www.ams.hi.is

Anderson, C. L., \& Bieniaszewska, R. L. (2005). The role of corporate social responsibility in an oil company's expansion into new territories. Corporate Social Responsibility and Environmental Management, 12, 1, 1-9.

Atlantic Supply Base (2011). P/F Atlantic Supply Base - Ársfrásøgn 2011. Tórshavn, Faroe Islands: Skráseting Føroya.

Bertelsen, R.G. \& Hansen, K.G. (2015). From Energy to Knowledge? Building Domestic KnowledgeBased Sectors around Hydro Energy in Iceland and Greenland. In Diplomacy on Ice, eds. S. Ali \& R. Pincus, Yale University Press, New Haven, CT, 113-127.

Bertelsen, R.G., Justinussen, J.C.S. \& Smits, C. (2016). Informal skills for building international economies in Iceland, the Faroe Islands and Greenland. Copenhagen: Greenland Perspectives Everybody on Board, in press.

Bertelsen, R.G., Justinussen, J.C.S. \& Smits, C. (2015). Energy as a developmental strategy for North Atlantic microstates in search of independence: creating knowledge-based energy sectors in Iceland, Faroe Islands and Greenland. In The Handbook of the Politics of the Arctic, eds. G. Hønneland \& L.C. Jensen, Edward Elgar Publishing.

BMP (2009). Guidelines for Social Impact Assessments for mining projects in Greenland. Retrieved 8 February 2016, from http://www.govmin.gl

Boutilier, R.G. (2014). Frequently asked questions about the social license to operate. Impact Assessment and Project Appraisal, 32, 4, 263-272.

Eliasen, Meinhard (2013). Personal Communication 04.05.216.

Franks, D.M., Davis, R., Bebbington, A.J., Ali, S.H., Kemp, D., \& Scurrah, M. (2014). Conflict translates environmental and social risk into business cost. PNAS, 111, 21, 7576-7581.

Friðleifsson, I.B., Svanbjörnsson, A., \& Thorsteinsson, L. (1984). Icelandic experience in transfer of energy technology. Tímarit Verkfræðingafélags Íslands, 69, 6-10.

Giddens, A. (1990). The Consequences of Modernity. Stanford: Stanford University Press.

Guðrmundsson, V. (1910). Upphitun bæjar með jarðhita [Heating towns with geothermal heat]. Eimreiðin, 16, 1, 31-32.

Hagstova Føroya (2015). Arbeiðsfjøld og arbeiðsvirkin skift á kyn og bústað (2005-2014). Retrieved 10 February 2016, from http://www.hagstova.fo

Hagstova Føroya (n.d.). Rakstrarviðurskiftið gjaldsjavnans. Retrieved 23 November 2014, from http://www.hagstova.fo

Hall, N., Lacey, J., Carr-Cornish, S., \& Dowd, A.M. (2015). Social license to operate: Understanding how a concept has been translated into practice in energy industries. Journal of Cleaner Production, 86, 301-310. 
Harhoff, F. (1993). Rigsfællesskabet. Disputats, Københavns Universitet (Klim,).

Harvey, B., \& Bice, S. (2014). Social impact assessment, social development programmes and social license to operate: Tensions and contradictions in intent and practice in the extractive sector. Impact Assessment and Project Appraisal, 32, 4, 327-335.

IIED (2014). Drilling deeper into public opinion. Retrieved 24 October 2014, from http://pubs.iied.org Jarðfeingi (2016) Guidelines for grants from license holders to competence development. Retrieved 9 February 2016, from: http://www.jardfeingi.fo

Krúnborg Offshore (2012). Krúnborg Offshore P/F. Tórshavn, Faroe Islands: Skráseting Føroya.

Lloyds (2012). Arctic Opening: Opportunity and risk in the High North. Retrieved 27 July 2015, at http://www.lloyds.com/riskinsight

Luhmann, N. (1979). Trust and Power. John Wiley and Sons.

Mest (2013). PAM On \& Offshore. Retrieved 13 April 2015 from Mest: http://www.mest-fo.com

Ministry of Industry, Labour and Trade (2015). Guidelines for Social Impact Assessment in Greenland. Retrieved 26 January 2016, from: http://www.Itu.se/

Müller, J., \& Djurhuus, T. (2014). Oljan: føroysk vinnu- og samfelagsmenning í 25 ár. Tórshavn: Oljan 2014.

NASA (2013). Is a sleeping climate giant stirring in the Arctic? Retrieved 26 October 2014, from http://www.nasa.gov

National Energy Authority Orkustofnun (n.d.). Oil and Gas Exploration. Retrieved 10 February 2016, from: http://www.nea.is

Moffat, K., \& Zhang, A. (2014). The paths to social license to operate: An integrative model explaining community acceptance of mining. Resources Policy, 39, 61-70.

Morrison, J. (2014). The social license. How to keep your organization legitimate. New York: Palgrave Macmillan.

Naalakkersuisut (2014a). Ét land - ét arbejdsmarked. Beskæftigelsesstrategi 2014-2017. Retrieved 16 November 2014, from http://www.naalakkersuisut.gl

Naalakkersuisut (2014b). Grønlands olie- og mineralstrategi 2014-2018. Retrieved 16 November 2014, from http://www.naalakkersuisut.gl

Naalakkersuisut (2014c). Impact Benefit Agreement under Mineral Exploration Licence 2014/21 between True North Gems Greenland - Kommuneqarfik Sermersooq - Naalakkersuisut. Retrieved 16 November 2014, from http://www.naalakkersuisut.gl

Nordal, J. 1973, "Um nýtingu vatnsafls og stefnuna í orkumálum: Erindi flutt á miðsvetrarfundi Sambands íslenzkra rafveitna 6. marz 1973" in 14. Mið̌svetrarfundur Sambands íslenzkra rafveitna.

Nordal, J. \& Kristinsson, V. (eds) 1996. Iceland, the Republic: handbook. Reykjavik: Central Bank of Iceland.

Oljumálaráðið (2003). Leiðreglur í samband við stuðul frá loyvishavarum til vinnuliga førleikamenning Tórshavn: Føroya Landsstrýrið. 
Oljuráoleggingarnevndin (1997). Fyrireikingar til oljuleiting: frágreiðing frá Oljuráðleggingarnevnd landsstýrisins. Tórshavn: Oljuráoleggingarnevndin vegna Føroya landsstýri.

Oljuvinnufelagið (2013). Ársfrágreiðing fyri 2013. Retrieved 10 February 2016, from

$\mathrm{http} / / \mathrm{www}$.vinnuhusid.fo

Owen, J.R., \& Kemp, D. (2013). Social license and mining: A critical perspective. Resources Policy, 38, 29-35.

Pálmason, G. (ed) 2005, Jarðhitabók, eðli og nýting auðlindar [The book on geothermal heating: the nature and use of resources], Hið íslenska bókmenntafélag, Reykjavík.

Pfeifer, S., \& C. Thompson (2011). The struggle for Greenland's oil. Retrieved 20 October 2014, from http://www.ft.com/

Prno, J. (2013). An analysis of factors leading to the establishment of a social license to operate in the mining industry. Resources Policy, 38, 577-590.

Prno, J., \& Slocombe, D.S. (2012). Exploring the origins of 'social license to operate' in the mining sector: Perspectives from governance and sustainability theories. Resources Policy, 37, 346-357.

Skansi (2013). Skansi Offshore awarded contract from Statoil. Retrieved 13 April 2015, from Skansi: http://www.skansi.fo/index.php/38-skansi-offshore-awarded-contract-from-statoil

Smits, C.C.A., Bertelsen, R.G. \& Justinussen, J.C.S. (2014a). The challenges \& opportunities for Arctic microstates in developing an energy sector: The role of human capital and knowledge institutes. Arctic Yearbook, 3, 1, 1-17.

Smits, C.C.A., van Tatenhove, J.P.M., \& van Leeuwen, J. (2014b). Authority in Arctic governance: Changing spheres of authority in Greenlandic offshore oil and gas developments. International Environmental Agreements: Politics, Law and Economics, 14, 4, 329-348.

Smits, C.C.A., Justinussen, J.C.S. \& Bertelsen, R.G. (2015). Oil and Gas Development in the Faroese Islands, Iceland and Greenland: How Local Competence Development Contributes to a Social License to Operate. Offshore Technology Conference, 2015/03/23-25.

The Economist (2004). Climate change: A canary in the coal mine. Retireved 26 October 2014, from http://www.economist.com

Thomson, I., \& Boutilier, R.G. (2011). Modelling and Measuring the social license to operate: Fruits of a dialogue between theory and practice. Retrieved 17 June 2015, from http://sociallicense.com

Thor (2011). Thor P/F - Ársfrásøgn við samtaksroknskapi 2011. Tórshavn, Faroe Islands: Skráseting Føroya.

United Nations Development Programme (n.d,). Human Development Reports. Retrieved 20 September 2015, from United Nations Development Programme:http://hdr.undp.org/en

USGS (2008). 90 barrels of oil and 1,670 trillion cubic feet of natural gas assessed in the Arctic. Retrieved February 8, 2012, from U.S. Geological Survey: http://www.usgs.gov

Vennix, J. (2006). Theorie en praktijk van empirisch onderzoek. Harlow: Pearson Education Ltd.

World Bank (2003). Striking a better balance: The World Bank and Extractive Industries. Retrieved 21 September 2015, from World Bank: http://web.worldbank.org 
Yates, B.F., \& Horvath, C.L. (2013). Social License to Operate: How to get it, and how to keep it. Pacific Energy Summit 2013.

Yin, R. (2009). Case study research: design \& methods. Los Angeles: Sage.

Zucker, L.G. (1986). Production of trust: Institutional sources of economic structure. In B. M. Staw and L.L. Cummings eds. Research in organisational behaviour. Greenwich: JAI Press. 